DOI: https://doi.org/10.32839/2304-5809/2021-5-93-38

УДК 378.016:81`243

Гапоненко Л.П.

Криворізький державний педагогічний університет

\title{
ГРА ЯК НАВЧАННЯ, НАВЧАННЯ ЯК ГРА
}

\begin{abstract}
Анотація. В представленій на розгляд статті автором досліджено методико-теоретичні питання використання ігрового методу в навчанні студентів іноземних мов. Розглянуто дослідження методистів, психологів і лінгвістів щодо застосування ігрових методів насамперед під час вивчення іноземних мов. Представлено теорії ігор та їх класифікації, розроблені різними науковцями. В статті наводяться приклади ігор та методика їх практичного впровадження під час навчання іноземних мов. Автор докладно показуе ігри для роботи з текстами. Наведені приклади ігор пропонуеться проводити на різних етапах навчання, задля досягнення різних цілей та з використання індивідуального та диференційованого підходу до кожного студента. Матеріали, які представлені в статті, можуть мати практичну цінність та застосовуватися під час навчання іноземних мов.
\end{abstract}

Ключові слова: гра, ігровий метод, класифікація ігор, комунікативна ситуація, спілкування.

Haponenko Larysa

Kryvyi Rih Pedagogical University

\section{A GAME AS LEARNING, LEARNING AS A GAME}

Summary. In the article presented for consideration, the author investigates methodological and theoretical issues of using the game method in teaching students foreign languages. The research works of methodologists, psychologists and linguists on the game method and its application in teaching foreign languages are considered. Game theories and their classifications developed by various scientists are presented. The article provides examples of games and methods of their practical implementation during foreign language teaching. The author shows in detail the games for working with texts. These examples of games are proposed to be conducted at different stages of learning, in order to achieve different goals and to use an individual and differentiated approach to each student. The materials presented in the article can have practical value and can be used in foreign language teaching. Research work and teaching experience show that real changes in the teaching of students of non-philological specialties of a foreign language as a means of communication still need changes and adjustments. So, as one of the methods, we propose to use a simulation-game model during training. Such a model, in our opinion, will help students to use educational material not as something abstract, but as a living example of communicative situations as close as possible to those that occur in real communication situations. The analysis allows us to observe significant changes in the communicative behavior of students, increasing their interest and motivation. The game has a positive effect on the process of learning the material and the quality of students' knowledge. The change in the position of the teacher and his role in this process are mentioned. In today's student-centered education, the teacher is like a mentor and is an equal partner in the communicative learning process. Thus, we observe that creativity, collaborative activity, tolerance and empathy are necessary features of a modern teacher. Partnership and the ability to play a role in a given situation brings educational activities to a new kind of interaction with students, for whom, in turn, the situation acquires personal value. All this will help to increase the motivation in learning and self-improvement of students.

Keywords: game, game method, games`classification, communicative situation, communicative process.

Постановка проблеми. Розвиток сучасної освіти характеризуеться модернізацією та вдосконаленням всіх сфер навчання. Навчання іноземних мов також досить чуттево реагує на ці зміни і на виклики, які ставе суспільство перед сучасним конкурентноздібним фахівцем. Знання іноземної мови стає нормою для успішного розвитку суспільства та участі в цьому процесі молодих спеціалістів-фрахівців. Все це зумовило зростання інтересу до іншомовної освіти, спрямованої на підвищення рівня володіння іноземною мовою та розвиток комунікативної компетенції фрахівця. Тому досить гостро перед сучасними викладачами постає проблема пошуку ефрективних методів вдосконалення та навчання іноземних мов. Використання ігрової моделі навчання іноземних мов може слугувати одним із шляхів поліпшення якості викладання.

Аналіз останніх досліджень і публікацій. Теорія гри і імітаційно-ігровий підхід були об'єктом досліджень цілої низки методистів, лінгвістів, педагогів. Ще К.Д. Ушинський пи- сав про застосування гри та їі значення: "У грі формуються всі сторони дитячої душі, розум дитини, його серце й воля, і якщо говорять, що дитячі ігри підказують майбутній характер і долю дитини, то це правильно: гра має великий вплив на розвиток дитячих здібностей і нахилів” [5, с. 620]. Це твердження може бути справедливо віднесено й до професійної підготовки студентів: дидактичні властивості ігор знаходять своє активне застосування під час професійного становлення студента. Двоплановість у грі, поєднання реальних подій і навчальних ситуащій, що програються під час гри, збагачує студентський досвід та знімає певні психологічні бар'єри.

Теорією ігор та розробкою їх класифікацій займалися чимало методистів та дослідників. Одну із перших класифікацій ігор розробив К. Гроос. Він розглядав ігри як експериментальні («ігри звичайних фрункцій») та спеціальні («ігри спеціальних фрункцій»). Швейцарський психолог Ж. Піаже розробив свою відому класифікацію ігор: 1) ігри-вправи (використовуються 
у перші місяці життя дитини, для того, щоб навчити їі певним базовим речам); 2) символічні ігри (такі ігри є поширеними у дітей від двох до чотирьох років); 3) ігри за правилами (поширені у дітей від семи до дванадцяти років) [7].

Ще одна класифрікація була наведена Д. Хедфрілд. Тут саме йдеться мова про ті ігри, які використовуються у навчанні іноземної мови. Вона запропонувала розділяти мовні ігри у два способи. У першій класифікації ігри були поділені на комунікативні та лінгвістичні. Друга класифікація має більше груп. Розглянемо ії:

1. Ігри на сортування та організацію (sorting, ordering, or arranging games). Наприклад, учню дають картки з назвами фруктів та овочів, які треба розподілити на дві категорії.

2. Ігри 3 інформаційним розривом (information gap games). Коли один учень має інфрормацію, яка необхідна іншому для виконання завдання. Наприклад, один з учнів має малюнок, який йому потрібно описати для того, щоб другий учень зміг його намалювати.

3. Ігри на відгадування (guessing games). Один 3 різновидів ігор 3 інфрормаційним розривом. Прикладом є популярна гра «Хто я?».

4. Пошукові ігри (search games). Теж різновид ігор з інформаційним розривом.

5. Ігри на співпадіння (matching games). Учасникам потрібно знайти співпадіння зі словом, картинкою або карткою.

6. Ігри 3 маркуванням (labeling games). Це форма відповідності, в якій учасники збігають ярлики та картинки.

7. Ігри 3 обміном (exchanging games). У цих іграх учні обмінюються картками, іншими предметами чи ідеями.

8. Настільні ігри (board games). Ерудит - одна 3 найпопулярніших настільних ігор, яка допомагає навчити правильному правопису слів.

9. Рольові ігри (role play games). До цієї категорії відносять такі терміни як "рольова гра», «драма" та «симуляція». Рольова гра може включати ролі, які учні не виконують у реальному житті, наприклад, стоматолога, тоді як симуляції можуть включати ролі, які учні вже виконують у реальному житті, наприклад покупця у магазині. Драми ж це вистави за сценарієм [8].

Ще одна відома класифікація була розроблена М.Ф. Строніним, він поділяе ігри на 5 категорій: 1) лексичні (використовують для того, щоб тренувати вживання лексики у ситуаціях, які наближені до реального життя. Мета: активізувати мовно-мислительну діяльність; розвинути мовну реакцію учнів; ознайомити учнів зі сполучуваністю слів.); 2) граматичні (Мета: навчити учнів вживанню мовних зразків, що містять певні граматичні труднощі; створити природну ситуацію для вживання даного мовного зразка.); 3) фонетичні (Мета: тренувати в учнів вимову англійських звуків.); 4) орфографрічні (Мета: тренувати написання англійських слів; тренувати пам'ять.); 5) творчі (Мета: сприяти подальшому розвитку мовних навичок та умінь) [3].

Виділення невирішених раніше частин загальної проблеми. Дослідницька робота та викладацький досвід показують, що реальні зміни в навчанні студентів нефілологічних спе- ціальностей іноземної мови як засобу спілкування ще потребують змін та внесення коректив. Отже, як один із методів ми пропонуємо використовувати імітаційно-ігрову модель під час навчання. Така модель, на нашу думку, буде сприяти тому, що студенти будуть використовувати навчальний матеріал не як щось абстрактне, а як живий приклад комунікативних ситуацій, максимально наближених до тих, які зустрічаються в реальних ситуаціях спілкування.

Мета статті: розглянути можливості ігрового методу задля оптимізації процесу навчання студентів іноземній мові та запропонувати варіанти ігор для практичного застосування.

Виклад основного матеріалу дослідження. Під час вивчення іноземної мови імітація фонетичних і лексичних особливостей та програвання навчальних комунікативних ситуацій $є$ постійною практикою та є найпоширенішим видом діяльності. Використання ігор забезпечуе певні можливості: ілюстрація певних правил вимови, вживання, граматичних конструкцій, діалогічне та монологічне мовлення тощо. Важливе значення гри полягає в тому, що вона активізує розумову діяльність студентів за рахунок того, що в основу любої гри покладено творче завдання. Задля його вирішення та розв'язання студент має проаналізувати ситуацію, залучивши свої наявні знання, вміння та навички.

Використання ігор може бути застосоване на різних етапах навчання. Призначення та мета гри визначається навчальними програмами, конкретними ситуаціями та особливостями конкретної групи. В нашій практичній діяльності ми моделювали ігрові ситуащії двох типів: ситуації для роботи 3 текстами і загальнокомунікативні ігрові ситуації. Серед багатьох ігор наведемо до прикладу декілька. Гра “Знайди заголовок" ("Find the title"): студенти діляться на дві групи. Одна одержує тексти без заголовків, а інша - безліч заголовків. Тексти підбираються викладачем заздалегідь та мають профресійну спрямованість. Обсяг текстів розрахований на 3-5 хвилин ознайомлювального читання. Студенти першої групи ознайомлюються зі змістом своїх текстів, а інша група вивчає отримані заголовки. Потім студенти першої групи в процесі спілкування розповідають зміст ïx текстів, а студенти другої - слухають і пропонують заголовки, обірунтовуючи свій вибір; їх партнери $з$ першої групи можуть погодитися чи нi [1, с. 144].

"Віднови текст" ("Restore the text"). Текст заздалегідь розбивається на кілька частин і в такий спосіб змінюеться його послідовність. Студенти поділяються на групи і кожна група ознайомлюється зі змістом певного уривка. Потім усі студенти спілкуються, розповідаючи зміст свого уривка, і відновлюють логічну послідовність усього тексту, коментуючи й аргументуючи своє рішення. Кількість студентів у групах може варіюватися залежно від складності тексту і підготовленості студентів [1, с. 144].

"Продовжи текст" "Continue the text"). Студентам пропонуеться продовжити уривок 3 тексту, дібраного, як правило, 3 англійської чи американської літератури. Завдання викладача - підібрати текст маловідомий, 3 цікавим 
і неординарним сюжетом. Завдання студентів максимально виявити свою франтазію і творчі здібності. Цю гру можна застосовувати при роботі над домашнім індивідуальним читанням.

“Вибудуй логічно” ("Make it logical”). Ця гра націлена на вдосконалення вмінь і навичок студентів розуміти на слух іноземну мову, вербальне i невербальне спілкування, орієнтуватися в моделюючих ігрових ситуаціях; на вдосконалення вмінь будувати свої висловлювання іноземною мовою послідовно і логічно. Студентам пропонуеться прослухати невеликий текст (записаний на касету чи прочитаний викладачем) У цьому тексті навмисне порушена логічна послідовність подій, яку студенти повинні відновити. Для цієї гри використовувалися фрахові джерела, бралися уривки 3 художньої літератури. Цей вид роботи ефективно застосовувався нами при контролі самостійного або додаткового домашнього читання, оскільки дозволяв швидко і точно визначити, як засвоїли студенти матеріал і чи всі його засвоїли [3, с. 81].

“П'ять слів" ("Five words"). У ході ціеї гри закріплюеться лексичний матеріал аналізованого тексту. Група поділяеться на дві команди. Поки студенти одніеї команди рахують до п'яти, інша команда записуе п'ять нових слів з тексту на дошці, подаючи їх переклад. Потім команди міняються місцями. Команда, яка не впоралася з завданням, програє.

“Більше слів”. Ця гра націлена на активізацію лексики з вивчених тем. Утворюються дві команди. Кожна команда повинна назвати якнайбільше слів на задану їй букву. Виграє команда, що назвала більшу кількість слів.

Гру можна проводити й у письмовій формі. Представники команд записують слова на дошці. У цьому випадку при підведенні підсумків враховується не тільки кількість слів, але й правильність їх написання.

Текст $є$ головною навчальною і методичною одиницею. Він має стати реальною і продуктивною основою навчання студентів іншомовного спілкування, а для цього важливо навчити їх працювати 3 текстом, піддавати його матеріал різним операціям, враховуючи жанрові і стилістичні особливості. Для цього ми моделювали різні ситуащії для навчання студентів прийомів роботи 3 текстом на передтекстовому, текстовому і післятекстовому етапах. Знання таких прийомів дозволяе майбутнім педагогам опанувати навички самостійної роботи 3 текстом та монологічних висловлювань різного типу.

На передтекстовому етапі дії студентів спрямовані на диференціацію мовленневих одиниць і мовних зразків, їх виявлення в тексті, оволодіння різними структурними матеріалами (видо-часовими формами дієслова, словотвором тощо):

1. Заповніть пропуски словами, які підходять за змістом.

2. Виберіть із тексту слова, що стосуються названої теми.

3. Знайдіть синоніми, антоніми в ряді поданих слів.

4. Складіть речення з наведених слів.

5. Визначте за формальними ознаками, якою частиною мови є виділені слова.
На текстовому етапі передбачається використання різних прийомів одержання інформації і безпосередня робота з матеріалами тексту:

1. Знайдіть у тексті речення, які розкривають головну думку.

2. Виділіть ключові речення в кожнім абзаці.

3. Розташуйте окремі речення відповідно до логіки викладення матеріалу в тексті.

4. Складіть скорочений варіант тексту.

5. Назвіть слова чи речення, у яких виражається ставлення автора до названої теми.

6. Складіть тези до тексту.

На післятекстовому етапі діяльність студентів спрямована на виявлення основних елементів змісту тексту і передання основної ідеї прочитаного:

1. Передразуйте назву тексту.

2. Виберіть найбільш важливі сюжетні лінії тексту.

3. Поясніть значення окремої події для розвитку сюжету тексту.

4. Визначте авторську і свою оцінку описуваних подій і головних персонажів тексту.

5. Розширте абзац чи продовжіть уривок 3 тексту.

6. Складіть короткий переказ чи усне повідомлення.

7. Обговоріть сюжетну лінію тексту.

Поєднання гри та традиційних форм і методів навчання змінюе процес навчання на більш едективний. Активне залучення та участь студентів в таких ситуащіях прискорюе засвоєння навчального матеріалу та процесу оволодіння навичками комунікативної взаємодії. Під час ігрового навчання студент програє певну відведену його роль, що перетворюе його на суб'єкта, який має активну комунікативну позицію й має право самовиражатися й відстоювати саме свою власну думку.

Оскільки головною діючою особою при імітаційно-ігровому підході знаходиться студент, то ми вважаємо, що ігрові й імітаційні форми містять необхідний потенціал для розвитку самодостатньої особистості майбутнього педагога, який здатний творчо мислити, адекватно реагувати на соціальні й культурні зміни та попит, відповідати вимогам і уявленням про вчителяпрофресіонала, що готуе гідну зміну, гідно виховуючи і навчаючи нове покоління.

Висновки. Проведений аналіз дозволяе нам спостерігати значні зміни в комунікативній поведінці студентів, підвищенню їх зацікавленості та вмотивованості. Гра позитивно впливає на процес засвоєння навчального матеріалу та на якість знань студентів. Зауважимо й на зміні позицій викладача та його ролі в цьому процеci. В сучасних умовах освіти, яка орієнтована на студента, викладач постає консультантом та рівноправним партнером комунікативного навчального процесу. Отже, ми спостерігаємо, що співтворчість, спільна діяльність, толерантність та емпатія являються необхідними рисами сучасного викладача. Партнерство та вміння програти певну роль в заданій ситуації виводить навчальну діяльність на новий вид взаємодії зі студентами, для яких, в свою чергу, ситуація набуває особистісної цінності. Все це сприятиме підвищенню вмотивованості навчання та самовдосконаленню у студентів. 


\section{Список літератури:}

1. Деркач А.А., Щербан С.Ф. Педагогическая эвристика: Искусство овладения иностранным языком. Москва, 1991. $224 \mathrm{c}$

2. Стронин М.Ф. Обучаюшие игры на уроке английского языка: (Из опыта работы). Пособие для учителя. Москва, 1981. $112 \mathrm{c.}$

3. Тарнопольский О.Б., Димова Л.С. Обучение этикету иноязычного повседневного, педагогического и делового общения в языковом вузе: предисловие к исследованию. Інозелні мови. 1999. № 1. С. $29-31$.

4. Ушинский К.Д. Собр. соч. Т. 2. Москва, 1954. 734 с.

5. Livingstone C. Role play in Language Learning. London, 1983. 94 p.

6. Piaget J. The Moral Judgment of the Child. London: Kegan Paul, Trench, Trubner and Co., 1932. 434 p.

7. Hadfield, J. Elementary vocabulary games. Harlow: Pearson Education Limited, 1998. 120 p.

\section{References:}

1. Derkach A.A. (1991) Pedagogicheckaya evristika: Iskustvo ovladeniya inostrannym yasykom. Moscow, 224 p.

2. Stronin M.F. (1981) Obuchayuschie igryi na uroke angliyskogo yazyika: (Iz opyita raboty). Posobie dlya uchitelya. Moscow, $112 \mathrm{p}$

3. Tarnopolskiy O.B., Dimova L.S. (1999) Obuchenie etiketu inoyazyichnogo povsednevnogo, pedagogicheskogo i delovogo obscheniya v yazyikovom vuze: predislovie k issledovaniyu. Inozemni movi, vol. 1, pp. 29-31.

4. Ushinskiy K.D. (1954) Sobr. soch., vol. 2. Moscow, 734 p.

5. Livingstone C. (1983) Role play in Language Learning. London, 94 p.

6. Piaget J. (1932) The Moral Judgment of the Child. London: Kegan Paul, Trench, Trubner and Co., 434 p.

7. Hadfield J. (1982) Elementary vocabulary games. Harlow: Pearson Education Limited, 120 p. 